\title{
Adverse Event Associated with Death
}

National Cancer Institute

\section{Source}

National Cancer Institute. Adverse Event Associated with Death. NCI Thesaurus. Code C53787.

An adverse event resulting in death. 